\title{
News, Notes and Queries
}

overseas visitors to the Congress. In addition to lectures, several excursions and sightseeing trips are being arranged.

The Registration Bureau will be open from 9 a.m. on I September at the School of Pharmacy, University of London, 29/30 Brunswick Square, London, W.C.I.

\section{FRANGIS A. COUNTWAY LIBRARY OF MEDICINE}

ON Wednesday and Thursday 26 and 27 May 1965, the Francis A. Countway Library was opened. The Library brings together the extensive resources of the Boston Medical Library and the Harvard Medical Library. The combined collections are intershelved and all the services integrated to create the largest university-centred medical library in the United States.

The Countway's resources are widely diversified. The historical collections rank among the country's most extensive in early American medical imprints. They are similarly strong in sixteenth century imprints in general. The collections of Judaica and Hebraica are world-renowned. These resources make the Countway an important centre for the study of the history of medicine.

\section{THE SIXTH INTERNATIONAL CONGRESS OF NEOHIPPOCRATIC MEDICINE}

Tне Sixth International Congress of Neohippocratic Medicine will be held in Madrid on 13-18 September 1965. Lectures will be given on the following subjects: 'The Physician facing the human Life', by Prof. Dr. Arasa and Prof. Dr. Gũy Laroche; 'Diseased Oscillations and Compensations,' by Prof. Dr. Martiny and Prof. Descloux; 'Incorrect Medications', by Prof. Velazquez and Prof. Dr. Stroender; and other short communications may be offered by delegates.

Simultaneous translation into several languages has been arranged, and interpreters provided. There will also be varied exhibition of books on Neohippocratic and related subjects.

Anyone wishing for further information concerning the Congress should write to the Secretary General: Medinaceli, 4, Madrid 14 (Spain).

\section{Society Reports}

\section{AUSTRALIAN MEDICAL ASSOGIATION}

(VICTORIAN BRANGH)

(Section of Medical History)

The Annual Meeting of the Section of Medical History was held on Monday 12 April 1965, in the Museum of the Medical Society of Victoria, East Melbourne. The following Office Bearers were appointed:-

President - Dr. Edward Ryan

Honorary Secretary - Dr. M. L. Verso

Honorary Treasurer - Dr. Una Shergold

The speaker for the evening was Dr. J. L. Evans, Psychiatrist Superintendent, Mental Hospital, Sunbury, who presented a paper 'Witchcraft, Demonology and Renaissance Psychiatry'. In his talk Dr. Evans emphasized how in the past, mental illness had been attributed to supernatural causes, and to witchcraft. Many so-called witches, were, in fact, psychotics or seriously disturbed hysterics, and victims of their 


\section{Neres, Notes and Queries}

own mental disorder. During the Renaissance the systematic study of witchcraft and demonology was at its height, but despite the widespread belief in witchcraft, many enlightened men had the courage to express views in opposition to the superstitions of the age.

The Annual Dinner of the Section of Medical History was held in the Union House, Melbourne University, on Friday 14 May, 1965. The Guest of Honour was Sir Denis Browne, Consultant Surgeon, Great Ormond Street Hospital for Sick Children, who was accompanied by Lady Browne.

\section{Book Reviews}

Saturn and Melancholy: Studies in the History of Natural Philosophy, Religion and Art, by R. Klibansky, E. Pan FsKy and F. Saxi, London, Nelson, 1964, pp. xviii, 429, Front., 146 illus. on plates, 5 text illus., $£ 66 s$.

Humoralism is the marrow of medicine-today more than ever. Even the rumbustious destroyer of ancient humoralism, Paracelsus, could not help employing the doctrine of temperaments. His psychology and pathology of war, religious strife and martyrdom visualized the warrior as choleric and the heretic as melancholic. He thus found extenuating circumstances for the anabaptists in their psychosomatic make-up, explained in terms of ancient humoralism, as was recently shown by $\mathrm{K}$. Goldammer (Psychiatrie und Gesellschaft, Bern and Stuttgart, 1958, pp. 90-101). A full history of the doctrine of temperaments has been one of the major desiderata in the history of medicine, natural philosophy, art and religion. So far the only work which provided essential information on the subject, accessible in book form, was Panofsky and Saxl's classic, Dürer's 'Melancholia I' (Studien der Bibliothek Warburg, Leipzig, 1923). Although drawing on material from many fields it was largely a study in the history of art and symbolic imagery. Moreover, the book had gone out of print not long after its first appearance. For many years a second enlarged edition had been contemplated and actually begun, but it seemed that it had become a victim to the scythe of Saturn. With the book under notice much more is being presented than a second-Englishedition of Panofsky and Saxl-an achievement that has been made possible by co-opting a third author: Professor Raymond Klibansky, Platonist, mediaevalist and critical editor of Nicolaus Cusanus, distinguished for more than thirty years' brilliant research into the philosophy of cosmos and man in the Renaissance.

In its present form the book cuts across all the fields that come within the scope of the subject. A full account of the notion of melancholy and its historical development notably includes the revolutionizing of this concept by the Aristotelian School (as laid down in Problemata, xxx, I), with the result that it was Aristotelian natural philosophy which first brought about the union between the purely medical notion of melancholy and the Platonic conception of frenzy (p. I 7). The other great theme is the introduction of Saturn as the 'Star of Melancholy' with special reference to Arabic astrology, to mythography and Neoplatonism. Pictorial tradition, poetry and especially Dürer -his sources and the artistic legacy of his 'Melancolia I'-still occupy a large portion of the work. Yet this is a work quite different from the original owing to the widening of its compass, the mass of new material included, its clear presentation and the opening up of many new perspectives in the history of medicine, philosophy and art. The chapters on 'Melancholia generosa'-the glorification of melancholy and Saturn in Florentine Neoplatonism (Marsilio Ficino) and the birth of the modern notion of 